\title{
AN ANALYSIS OF HETEROTIC POTENTIAL FOR AGRONOMICALLY IMPORTANT TRAITS IN SUNFLOWER (Helianthus annuus L.)
}

\author{
Škorić, D. ${ }^{1 *}$, Jocić, S. ${ }^{1}$, Hladni, N. ${ }^{1}$ and Vannozzi, G.P. ${ }^{2}$ \\ ${ }^{1}$ Instutute of Field and Vegetable Crops, 21000 Novi Sad, Serbia \\ ${ }^{2}$ Faculty of Agroeconomy, University of Udine, Udine, Italy
}

Received: October 10, 2006 Accepted: May 15, 2007

\section{SUMMARY}

Study of inbreeding and heterosis in sunflower has been taking place for over 80 years now. Practical application of the phenomenon of heterosis in this species began after the discovery of a suitable source of cytoplasmic male sterility in 1969 and that of restorer genes.

Many authors have reported significant manifestation of heterosis for seed yield and yield components as well. Also, the mode of inheritance of agronomically important traits in the $F_{1}$ and $F_{2}$ generations has been thoroughly examined. Positive correlations for yield have been established between parental lines and $F_{1}$ hybrids. The GCA and SCA for yield and yield components have been well studied. Solutions have been suggested on how to increase the harvest index and sink capacity as well as the contributions of individual physiological parameters in the process of yield augmentation.

In order to increase heterotic effects for seed yield and oil yield and direct and indirect yield components, it is necessary to increase the genetic variability of pre-breeding materials, achieve improved efficacy at the inbreeding stage, and streamline and accelerate the process of GCA and SCA evaluation using molecular markers and other biotechnology methods in order to achieve breeding goals.

Seed oil content should be increased to over 55\% using recurrent selection methods. Special focus in breeding programs should be placed on the development of high-oleic hybrids ( $>95 \%$ ) with a high genetic potential for oil yield, resistance to the dominant diseases, and wide environmental adaptability that would be used for industrial purposes (production of biodiesel, or hydrogen). In order to extent the duration of sunflower oil stability, beta, gamma and delta tocopherols should be incorporated instead of alpha ones alongside the $\mathrm{Ol}$ genes. The exiting genetic variability of the cultivated sunflower makes it possible to develop hybrids with a genetic potential for seed yield of over 6 t/ha and seed oil content of over 55\%. Most often, however, sunflower yields obtained in large-scale commercial sunflower production are in the 1.5-3.0 t/ha range. There are multiple limiting factors preventing the reali-

\footnotetext{
* Corresponding author: e-mail: draganskoric@sbb.co.yu
} 
zation of the high genetic potential of this crop. Their removal will enable commercial sunflower yield to stabilize at levels of $4 \mathrm{t} / \mathrm{ha}$ and above.

Diseases are the main limiting factor affecting sunflower production in all sunflower-growing parts of the world. Development of exotic germplasm through further use of wild sunflower species, distant hybridization and genetic transformations should be used to provide genes for resistance to all dominant pathogens and broomrape.

Efficient breeding methods should be employed to increase sunflower tolerance of air and soil drought and salinity and to attain wider resistance to herbicides.

Key words: sunflower, breeding, yield, heterosis, oil quality, resistance, pathogens, drought

\section{INTRODUCTION}

Breeders have at their disposal relevant contemporary knowledge from the fields of genetics and plant breeding. In addition, the modern plant breeder needs to have adequate knowledge of the allied biological disciplines, such as plant pathology and entomology (breeding for protection purposes), plant physiology, agronomy and soil sciences (breeding for commercial production purposes), biochemistry and molecular biology (genetic engineering and molecular breeding) and statistics (the most essential and useful tool in plant breeding). The plant breeder is not a white-collar executive. He needs to study plants, for which he has to be in the field, close to the plant. As Borlaug, a Nobel laureate, rightly remarked, "Plants do speak, but they only whisper, so to listen to them, you have to be by their side" (Sharma, 1994).

The sunflower is one of the four most important oil crops globally and is grown on over 21 million hectares worldwide. The cultivated sunflower originates from North America. After its arrival to Europe in the course of the $16^{\text {th }}$ century, some time had to pass before the sunflower become an agricultural crop. The sunflower as an oil crop was mentioned for the first time in writing in 1818 in Russia, and it started to be grown there on a large scale after 1830 (Morozov, 1947).

The beginning of scientifically based sunflower improvement dates back to 1912, when a program of varietal development was established in Russia (Krasnodar, Saratov, Armavir, Rostov-on-Don).

The largest contribution in developing productive high-oil sunflower cultivars was made by Russian breeders Pustovoit and Ždanov, who in the first half of the $20^{\text {th }}$ century developed a large number of varieties and increased the crop's seed oil content from $30-35 \%$ to $50-55 \%$. These Russian cultivars became the basis for the development of sunflower hybrids, which began when Leclercq (1969) found the first source of cytoplasmic male sterility and several other authors discovered $R f$ genes, marking the start of a new era in the advancement of sunflower production. 
Soon thereafter, the new type of sunflower product spread across a number of countries.

In parallel with the cultivar development, research was being carried out on inbreeding and heterosis, but the actual use of the phenomenon of heterosis in sunflower could not get under way because of the bisexual nature of the flowers of this crop. The first findings on heterosis and inbreeding in sunflower were published by Plaček (1915, 1927, 1930, 1936), Yagodkin (1937), Morozov (1936, 1947), Habura (1958), Putt (1962), Schuster (1962 and 1964), Gundaev (1965), and Popov et al. (1966), and these were followed by many others later on.

In the last three decades, a large number of authors have studied in detail sunflower inbreeding, heterosis, and the mode of inheritance of major traits.

\section{Objective of this paper:}

Using our own results and findings made by the NS sunflower team and various other researchers worldwide, we discuss in the present paper the achievements of sunflower breeding with special focus on:

- the effort to increase average sunflower yields to over 4 t/ha based on the manifestation of heterosis and mode of inheritance of certain traits;

- the increase of stability and adaptability of newly developed sunflower hybrids; and

- the identification of limiting factors in sunflower production and their elimination by the use of modern findings on sunflower genetics and breeding.

\section{Yield and yield components}

The main goal of plant breeding is to increase yields, and it is this object that all the other goals in breeding for individual traits are ultimately subordinated to. Yield is not a simple trait; rather, it is a complex one, an aggregate of traits, or a super trait. In breeding for yield, it is important to identify components that can be easily morphologically determined in the various stages of ontogenesis and that show correlations with yield, so that selection for them can in fact become selection for yield (Borojević, 1981).

Sunflower seed yield is a complex trait with polygenetic base that is highly influenced by the environment. Since seed yield is the main focus on attention of virtually all breeders, there are a large number of papers dealing with the mode of inheritance of this trait in sunflower. Still, the results of these studies are not in complete agreement with each other. All of them agree that both the additive and nonadditive components of genetic variance play a role in the inheritance of seed yield.

Sunflower seed yield is a product of three main yield components, namely plant number per unit area, seed number per plant, and seed mass. Sunflower yield per unit area can be increased in a number of ways. One of the main ones is to increase 
seed number and seed size per head while maintaining or increasing plant number per unit area (Merrien, 1992).

The ultimate components of seed yield (yield in the broad sense) and oil yield per unit area (yield in the narrow sense) in sunflower are: plant number per hectare $(55,000-70,000)$, seed yield per plant $(>1,500)$, test weight $(45-50 \mathrm{~kg} / \mathrm{ha}), 1,000$ seed mass ( $>80 \mathrm{~g})$, low hull content $(20-24 \%)$ and high seed oil content $(>55 \%)$ (Škorić et al., 2000).

With the attainment of these values in each of said traits, we can expect to reach our desired goal, i.e. an oil yield per hectare of 3,000 $\mathrm{kg}$ and more. In order to do so, it is important to perform selection for the above traits when developing self-pollinated lines as well as to know the mode of inheritance and heterotic properties of the traits in question and how they correlate to each other, so that productive hybrids possessing desirable characters can be developed (Škorić, 1992).

The existing genetic variability of the cultivated sunflower makes it possible to develop hybrids with a genetic potential for seed yield of over 6 t/ha and seed oil content of over 55\%. Most often, however, sunflower yields obtained in large-scale commercial production are in the 1.5-3.0 t/ha range.

There are multiple limiting factors preventing the realization of the high genetic potential of this crop. Their removal will enable commercial sunflower yields to stabilize at levels of $4 \mathrm{t} / \mathrm{ha}$ and above.

When it comes to the manifestation of heterosis and the mode of inheritance of seed yield (ha) in the $F_{1}$ generation, different authors have obtained different results. One group of authors gives more significance to the additive component (Putt, 1966; Sindagi et al., 1979; Sudhakar et al., 1984; Sheriff and Appadurai, 1985; Sigh et al., 1989; Petakov, 1992), whereas another argues that the nonadditive one is more important (Kovačik and Škaloud, 1972; Shrinvasa, 1981; Marinković, 1993; Lande et al., 1997; Bajaj et al., 1997; Rether et al., 1998; Kumar et al., 1998; Goksoy et al., 2000; Cecconi et al., 2000).

Epistatic gene effects have a significant role in the inheritance of seed yield per plant (Panchabhaye et al., 1998). Such effects are relatively more significant than the effects of addictive genes but generally less important than those of dominant genes (El-Hity, 1992). The same author considers the dominant $\times$ dominant gene epistasis to be of lesser importance than two-gene epistasis in the inheritance of seed yield.

Putt (1966) and Sindagi et al. (1979) determined that the general combining ability is more important for sunflower seed yield than the specific one, indicating that the additive component of genetic variance is more important than the nonadditive one. Kovačik and Škaloud (1972), Marinković (1984) and Mihaljčević (1989), on the other hand, found a larger role of the nonadditive component in sunflower seed yield inheritance. Also, an analysis of the combining abilities of 13 sunflower parental lines (10 female and three male ones) showed gene action for seed yield 
per plant to have been predominantly nonadditive. Parents that had good GCA and SCA for most yield components can be used in sunflower breeding (Tyagi, 1988).

Škorić (1989) argues that the best way to develop hybrids with a shorter stem is to shorten the internodes while maintaining photosynthetic area size per plant, the leaf area index and source capacity and increasing sink capacity, i.e. seed number and mass per plant and competitive ability in the agrocenosis. Newly developed $F_{1}$ hybrids of sunflower have a larger harvest index (0.30) than Soviet cultivars, but the value of the new index is still small compared with other field crops.

It is very important to study heterosis from the physiological, morphological and biochemical points of view, because these aspects directly determine yield levels, germination energy, plant growth, size of leaf area, intensity of photosynthesis and respiration, intensity of resynthesis and accumulation of organic substances in the seed, enzymatic activity, etc (Ćupina and Sakač, 1989).

In sunflower plants, the manifestation of heterosis is directly linked to the more effective utilization of chemical energy bound to the organic substrate. In agricultural plants in general, the physiological/biochemical basis of heterosis is highly complex. On the one hand, it is linked with the synthesis of organic matter using the Sun's energy. On the other, it is related to the utilization of these organic substances for plant growth and development, and especially for seed yield formation (Ćupina and Sakač, 1989). The former group of processes is connected with photosynthesis by plants.

Seed number has the largest direct influence on seed yield (Škorić, 1974; Marinković, 1987; Dušanić, 1998). Seed number per sunflower head is determined by the number of disk flowers formed, self-compatibility, attractiveness to pollinators, and environmental factors at flowering and pollination (Škorić, 1992). In order to reach the target number of over 1,500 seeds per plant, self-pollinated sunflower lines should be bred for a large number of disk flowers (Škorić, 1980).

When breeding for seed size, one must bear in mind the findings of Djakov (1981) according to which there is a high negative correlation between seed size and seed number per plant, because when a genotype produces more seeds, less resources are available to each seed formed (Škorić, 1989). Regression between seed number and seed size has the form of a hyperbola and correlation between these two traits is negative in character. Correlation between the 1,000-seed mass of parental line and that of their hybrids is medium high $(\mathrm{r}=0.63)$, while the average direct correlation with seed yield is 0.40 (Kovačik and Škaloud, 1990).

According to Kovačik and Škaloud (1972) and Goksoy et al. (2000), the nonadditive component of genetic variance is the only important component in the inheritance of 1,000-seed mass. By contrast, Rao and Singh (1977), Marinković (1984), Kesteloot et al. (1985), and Bajaj et al. (1997) all indicate the importance of the nonadditive component. Marinković and Škorić (1985), Kumar et al. (1998), Sassikkumar et al. (1999) and Goksoy et al. (2000) reported that both additive and nonadditive components of genetic variance had a role in the inheritance of 1,000 - 
seed mass, but also that the importance of the nonadditive component was greater. Such diametrically opposite results can be found in the literature for epistatic gene effects as well.

The level of self-fertility in a given genotype is an important component in the formation of yield per plant or yield per unit area (ha), because it also determines the number of seeds formed on each sunflower head.

Although additive and nonadditive gene action both plays a role in the inheritance of fertilization level, the nonadditive component of genetic variance is of greater significance (Joksimović, 1992; Joksimović et al., 1994). Marinković (1984) reported greater significance of the additive component. Holtom et al. (1995) found large importance of dominant gene effects and absence of epistasis effects in the expression of fertilization level. Gangappa et al. (1997), on the other hand, found two-gene epistasis effects in the inheritance of this trait.

As seed oil content definitely has a direct effect on the formation of oil yield per hectare, it is important sunflower breeders develop inbred lines with a seed oil content of over $50 \%$. The manifestation of heterosis for this trait as well as its mode of inheritance is highly important too.

Because oil yield per unit area (ha) is the ultimate goal of sunflower growing, along with studying the aforementioned direct oil yield components, the mode of inheritance of this complex character must be understood as well.

Schuster (1964) found dominance of the poorer parent in the inheritance of oil yield. According to Pustavoit (1966), the mode of inheritance of oil yield is intermediacy. Marinković (1984) reported dominance of the better parent in the inheritance of oil yield. Škorić (1976) found four different modes of oil yield inheritance in the $\mathrm{F}_{1}$ generation: intermediacy, partial dominance, complete dominance, and super dominance.

Putt (1966), Fick (1975), Škorić (1976), Marinković (1984) and Bedov (1985) all came to the conclusion that the role of the additive component of genetic variance was more important than that of the nonadditive one in the inheritance of this character in the $\mathrm{F}_{1}$ generation.

It is also important all direct and indirect oil yield components are studied in parallel. In Joksimović (1992), the largest average contributions to the expression of the traits were made by the female inbred lines for leaf blade dry matter mass and fertilization percentage, by the male inbreds (testers) for plant height, leaf area, stem dry matter mass, head dry matter mass, leaf petiole dry matter mass, and vegetative dry matter mass, and by the interaction for seed yield, kernel yield, oil yield, protein yield and harvest index. In the inheritance of plant height, seed yield, kernel yield and oil yield, only heterosis manifested itself. Leaf area, dry matter mass of leaf petiole, dry matter mass of vegetative plant parts, fertilization percentage, protein yield and harvest index were all inherited superdominatly and dominantly. In the inheritance of leaf blade dry matter mass, supedominance, dominance and par- 
tial dominance manifested themselves. Dominance and intermediacy were manifested in the inheritance of head dry matter mass (Joksimović, 1992).

The results of Hladni et al. (2005) shown below shed more light on the mode of inheritance of major sunflower traits.

Table 1: Mode of inheritance of agronomically important traits in the $\mathrm{F}_{1}$ generation

\begin{tabular}{|c|c|}
\hline Characteristic & $\begin{array}{l}\text { Line } \times \text { tester } \\
\text { Mode of inheritance }\end{array}$ \\
\hline Plant height & $\begin{array}{l}\text { The main role in plant height inheritance was played by the nonadditive } \\
\text { component of generic variance, as shown by analysis of variance of com- } \\
\text { bining abilities and analysis of genetic variance components. Further sup- } \\
\text { porting this conclusion was the fact that the GCA /SCA ratios for plant height } \\
\text { found in the } F_{1} \text { generation were below the value of one }(0.57) \text { in both study } \\
\text { years. }\end{array}$ \\
\hline Head diameter & $\begin{array}{l}\text { The main role in head diameter inheritance was played by the nonadditive } \\
\text { component of genetic variance, as shown by analysis of variance of combin- } \\
\text { ing abilities and analysis of genetic variance components. Further supporting } \\
\text { this conclusion was the fact that the GCA/SCA ratios for head diameter found } \\
\text { in the } F_{1} \text { generation were below the value of one }(0.08) \text { in both study years. }\end{array}$ \\
\hline $\begin{array}{l}\text { Total seed number } \\
\text { per head }\end{array}$ & $\begin{array}{l}\text { The main role in the inheritance of total seed number per head was played } \\
\text { by the nonadditive component of genetic variance, as shown by analysis of } \\
\text { variance of combining abilities and analysis of genetic variance components. } \\
\text { Further supporting this conclusion was the fact that the GCA/SCA ratios } \\
\text { found in the } F_{1} \text { generation were below the value of one }(0.11) \text {. }\end{array}$ \\
\hline 1,000 -seed mass & $\begin{array}{l}\text { The main role in the inheritance of } 1,000 \text {-seed mass was played by the } \\
\text { nonadditive component of genetic variance, as shown by analysis of variance } \\
\text { of combining abilities and analysis of genetic variance components. Further } \\
\text { supporting this conclusion was the fact that the GCA/SCA ratios found in the } \\
F_{1} \text { generation were below the value of one }(0.30) \text {. }\end{array}$ \\
\hline Seed yield per plant & $\begin{array}{l}\text { The main role in the inheritance of seed yield per plant was played by the } \\
\text { nonadditive component of genetic variance, as shown by analysis of variance } \\
\text { of combining abilities and analysis of genetic variance components. Further } \\
\text { supporting this conclusion was the fact that the GCA/SCA ratios found in the } \\
F_{1} \text { generation were below the value of one }(0.08) \text {. }\end{array}$ \\
\hline Oil content in seed & $\begin{array}{l}\text { The main role in oil content inheritance was played by the nonadditive } \\
\text { component of genetic variance, as shown by analysis of variance of combin- } \\
\text { ing abilities and analysis of genetic variance components. Further supporting } \\
\text { this conclusion was the fact that the GCA/SCA ratios for oil content found in } \\
\text { the } F_{1} \text { generation were below the value of one }(0.33) \text {. }\end{array}$ \\
\hline
\end{tabular}

\section{Increase of genetic variability in cultivated sunflower}

In order to achieve sunflower breeding goals, i.e. obtain highly productive hybrids, the genetic variability of the cultivated sunflower needs to be increased. The question is how this should be accomplished. There are definitely different ways and approaches for increasing the genetic variability of the cultivated sunflower. In parallel with increasing the genetic variability of future inbred lines used for obtaining superior combinations (hybrids), the adaptability of these lines to changed environmental conditions should be raised as well. 
According to Sharma (1994) there is no one genotype, either homo or heterozygous, that is likely to be a paragon of adaptability. However, the fact remains that some genotypes are better adapted over a range of environments than others. Because of $\mathrm{G} \times \mathrm{E}$ interaction, hybrids respond differently to different environments. According to the same author, breeding is the greatest source for all forms of adaptivity. He also raises the ever-present dilemma of which breeding direction to take in increasing the adaptability of hybrids, namely whether to develop hybrids that are: 1- well-adopted, by and large, to all environments, which is the most difficult of the three options as it requires the presence of very wide variability within the germplasm used; 2- well-adopted to rich environments; or 3- well adopted to poor environments. It is up to each individual breeder to decide for themselves which of these approaches will work best for them in the context of their own specific environments and available germplasm.

Given the limited genetic variability of the cultivated sunflower and the rich variability found in the wild species of the genus Helianthus, one of the sure ways to increase sunflower genetic variability is through the use of interspecific hybridization. The validity of this approach is confirmed by the previous experiences in the use of wild Helianthus species as sources of genes for resistance to various pathogens and herbicides and genes for oil quality and other agronomic traits.

The question is to what extent sunflower genetic variability for agronomically important traits can be increased using interspecific hybridization to obtain a high level of heterosis and enable the development of highly productive hybrids possessing adaptability levels greater than the existing ones. The answer is definitely to a great degree, provided suitable wild species of the genus Helianthus are chosen and the latest biotechnology methods are used to overcome the existing problems in the field of interspecific hybridization. The wild species can also be used to alter sunflower plant structure by developing cultivated sunflower genotypes with shorter internodes and much shorter petioles (H. mollis). This is the way towards a significant increase in the number of plants per unit area (ha) and hence the productivity of the future hybrids. It is also very important to direct the breeding efforts towards increasing the competitive ability of the sunflower root system, as this is also one of the ways by which plant number per unit area can be increased.

The wild species can also be used for increasing sunflower genetic variability with regard to more efficient and increased utilization of all plant organs (phytocompounds, rubber, nutritive value of sunflower leaves and stems in livestock nutrition, etc).

The genetic variability of the cultivated sunflower can be increased using all four types of recurrent selection, especially when it comes to quantitative traits. Increased genetic variability can also be achieved using population improvement, gene pools, synthetics, half-sib (HS) and full sib (FS) progenies, and so on.

The use of new biotechnology methods (embryo, tissue and anther cultures, protoplast fusion, genetic engineering, MAS (Marker-Assisted Selection), or molecu- 
lar breeding) makes it possible to significantly increase sunflower genetic variability, speed up the process of selection, and overcome a number of problems occurring in interspecific hybridization. This is confirmed by the results achieved so far, which show that biotechnology in sunflower breeding has made significant advances in solving certain problems in sunflower breeding at the tissue, cell and gene levels.

The completion of the above breeding tasks will make it possible to increase and stabilize sunflower production, increase its adaptability, and regularly obtain yields of over $4 \mathrm{t} / \mathrm{ha}$, resulting in greater competitiveness of this crop in large-scale commercial production.

By eliminating the limiting factors through genetic and breeding efforts (resistance to diseases, drought, salinity, etc), significant progress will be made in increasing the appeal of sunflower production, while altered oil and protein quality will make sunflower seeds a highly sought-after raw material for novel foods and non-food industries.

\section{Sunflower breeding for disease and pest resistance}

Diseases are a limiting factor in sunflower production in the majority of sunflower-growing countries. Different diseases are dominant in different regions on account of various agro ecological conditions prevailing in them. The cultivated sunflower has a narrow genetic base and is deficient in resistance genes (Škorić, 1988).

Over the past two decades, sunflower breeders have nevertheless managed to accomplish a lot in finding within the wild Helianthus species genes for a number of pathogens and incorporating them into inbred lines with good combining abilities, whereby significant progress has been made in sunflower breeding for resistance to diseases and pests.

Every sunflower breeder should study in detail the concept of disease and pest resistance. Most importantly, they should have a good knowledge of sunflower pathogens, their relationship with sunflower as the host, and the type and dynamics of the resistance (whether it is vertical or horizontal). Also, a sunflower breeder must be familiar with major approaches to management of resistance genes, stability (durability) of resistance, breeding strategies, operational tips and breeding objectives by genetic means. Breeding for pest resistance is even more difficult than breeding for resistance to diseases. Not enough researchers are working on it in the world and there are not enough genes in the genus Helianthus to provide resistance to particular insects.

Sunflower breeding has achieved significant results in finding in the wild Helianthus species genes for resistance or high tolerance to diseases and incorporating them into cultivated sunflower genotypes with good combining abilities.

The presence of genes for resistance to particular pathogens varies widely according to the species of wild sunflower. Reliable methods should therefore be used to determine the frequency of genes for each dominant causal agent of disease 
in each wild species of the genus Helianthus. Sunflower breeders have achieved different kinds of results in breeding for resistance to pathogens of this crop. These fall into several groups:

- Genetic resistance to causal agents of sunflower diseases (Plasmopara halstedii, Puccinia helianthi, Verticillium dahliae, Verticillium albo-atrum, and Erysiphe cichoracearum)

- A high level of tolerance (field resistance) (Phomopsis/Diaporthe helianthi, Macrophomina phaseolina, Albugo tragopogonis and Alternaria ssp.)

- Somewhat satisfactory tolerance (Phoma macdonaldi and Sclerotinia sclerotiorum - root and stem disease forms).

- Partial results with no satisfactory levels of tolerance/resistance as of yet (Rhizopus ssp., Botrytis cinerea and some other fungal pathogens, Škorić et al., 2006).

Sunflower breeders around the world should constantly monitor changes occurring in the racial composition of the pathogens so as to ensure success in the discovery of new genes in wild sunflower species and maintain control over the racial composition of dominant pathogens. Also, their use of molecular markers in breeding for resistance to diseases (molecular breeding) should be more rapid and daring. This is the only way to reduce to a reasonable level the negative impact of pathogens on the fulfillment of genetic potential for seed yield in sunflower.

Further work on finding sources of resistance to pathogens in the genus Helianthus must be a long-term orientation of sunflower breeders. Certain sources of resistance can also be found through the use of induced mutations.

Much more work should also be done on using certain wild sunflower species to improve cultivated sunflower resistance/tolerance of insects, which cause big problems in sunflower production in the U.S., Africa, Asia and Australia.

\section{Sunflower breeding for resistance to Orobanche cumana Wallr.}

The floriferous parasite broomrape (Orobanche cumana Wallr.) is an important limiting factor in sunflower production, especially in countries adjacent to the Black Sea as well as in Spain, Israel, Serbia, China and some other countries. It is, therefore, necessary not just to develop a highly productive hybrid but to determine genes for resistance to broomrape as well.

A great contribution to sunflower breeding for resistance to broomrape races A and B has been made by Russian breeders Ždanov and Pustovoit, who in the 1930s developed cultivars resistant to said races. It should be noted that genes for broomrape resistance are found in certain wild species of the genus Helianthus. Another important contribution to sunflower breeding for resistance to this parasite has been made by Galina Pustovoit, who between 1968 and 1980 developed several broomrape-resistant cultivars by interspecific hybridization using the wild species H. tuberosus as the donor of the resistance genes. 
Vranceanu et al. (1980) carried out the most detailed study of genetic resistance to broomrape in sunflower. They established the existence of five physiological races (A, B, C, D, E) within the broomrape population found in Romania and also discovered the differential lines and five different dominant genes (Or1, Or2, Or3, Or4 and Or5) controlling resistance to races A, B, C, D, and E.

Additionally, Pacureanu-Joita et al. (1998) found a source of resistance (Or6) to a new race of broomrape (F) in the line LC-1093, which originated from a Russian cultivars obtained by interspecific hybridization based on $H$. tuberosus.

The success of breeding for broomrape resistance is limited by the appearance of new races of Orobanche. Besides Romania, where race $\mathrm{F}$ has appeared, broomrape races $\mathrm{F}$ and $\mathrm{G}$ have also been reported in Spain. New races of broomrape have also appeared in Turkey (several of them), Bulgaria, Ukraine, Russia, Israel, China, and Iran (Škorić et al., 2006).

The fact that genes for resistance to all these races are found in certain wild sunflower species gives reason for optimism in the fight against new races of broomrape. Sunflower breeders use several methods for attaining broomrape resistance using artificial inoculation in the field, pots, greenhouse, and laboratories. More recently, molecular markers have been used in breeding for resistance to broomrape. Thus, Lu et al. (1999) were among the first to discover molecular markers for the Or5 gene (race E) using the RFLP technique. Similar results were reported by Gang et al. (2003 and 2004) and Sukno et al. (1999).

Highly significant results in the use of molecular markers in sunflower breeding against broomrape races have been achieved by Perez-Vish et al. (2004), who studied breeding materials using QTL-S, RFLP and SSR markers and found resistance to race $\mathrm{E}$ to be controlled by 5 markers (Or1.1., Or3.1., Or 7.1., Or 13.1., Or 13.2.) and that to race $\mathrm{F}$ by six $(\operatorname{Or} 1.1 .$, Or 4.1., Or 5.1., Or 13.1., Or 13.2., Or 16.1). These findings show that the use of molecular markers speeds up sunflower breeding for resistance to broomrape.

It should be noted that broomrape could also be successfully controlled by imidazolinone-based herbicides used in conjunction with hybrids resistant to this herbicide group. The source of resistance to imidazolinones was found in a population of wild H. annuus (Škorić et al., 2005).

\section{Sunflower breeding for resistance to drought}

In a number of countries, sunflowers are cultivated in semiarid and arid conditions, where severe soil droughts (and often atmospheric ones as well) are a limiting factor in crop production, regardless of the genetic potential of the hybrids grown.

Abundant literature exists on three adaptive mechanisms (escape, avoidance, tolerance) of plants to drought and on the genetic bases and genetic variability of these mechanisms. Several selection indexes and methods were found and utilized in breeding programs. In spite of all these efforts, breeding for drought stress remains a very difficult task for the scarce knowledge of the physiologic mecha- 
nisms of resistance, of their genetic basis and of appropriate screening techniques. (Monti, 1986).

Resistance of plants to drought can be the result of a large spectrum of mechanisms acting at different levels of the plant organization and at different stages of the life cycle. Morpho-physiological studies have detected several components conferring drought escape and avoidance. Indications concerning the basis of mechanisms controlling tolerance are obtained from analysis of physiological and molecular responses to drought stress and from the studies of differences within sunflower species (Ottaviano, 1986).

According to a number of researchers, defining the strategy for drought resistance breeding is not simple, as water stress is a complex phenomenon consisting of a number of different factors that contribute to yield losses to varying degrees depending on the time of appearance and severity of drought (Škorić, 2002).

Different research organizations use different techniques and physiological parameters when breeding for sunflower resistance to drought. Škorić (1992) lists over 30 different parameters (techniques) that are employed in breeding for drought resistance. Of those, the most frequently used ones are:

1. Use of productive, early-maturing hybrids

2. Leaf area duration (LAD)

3. Powerful root system

4. Concurrent breeding for resistance to M. phaseolina and Phomopsis

5. Increasing photosynthetic activity

6. Inducement of temperature shock in the plant

7. Increasing the rate of assimilate translocation from green plant parts to seeds

8. Turgor pressure

9. Leaf transpiration ( $\mathrm{Tr}$ ) and leaf resistance duration

10. Stomatal density

11. Osmotic pressure

12. Stress level (Ts-Ta); $\mathrm{Ts}=\mathrm{t}^{\mathrm{O}} \mathrm{C}$ on leaf surface; $\mathrm{Ta}=\mathrm{t}^{\mathrm{O}} \mathrm{C}$ of surrounding air

13. Leaf water potential

14. Abscisic acid accumulation in levels

15. Relative water loss (RWL).

According to Škorić (1989 and 1992) and Vranceanu (2000), it has been shown the most practical approach to sunflower breeding for drought resistance is the use of the stay-green phenomenon, which produces rapid and reliable results.

It is important to note that the use of a source genotype with the stay-green character increases not only drought tolerance but tolerance of Phomopsis and Macrophomina as well. Using stay-green for practical purposes is very easy, but the chosen genotype must have a high level of self-fertility, otherwise a big mistake will be made as the wrong genotype is selected. 
According to the results of Seiler (1983 and 1986), who used several physiological parameters to test wild sunflower species for tolerance to drought, the highest levels of drought tolerance are found in the wild species $H$. pumilus and $H$. maximiliani and some populations of the wild $H$. annuus. Breeders most often use $H$. argophyllus, but $H$. deserticola should not be overlooked either.

\section{Genetic possibilities for altering sunflower oil quality}

As the food industry demands fats and oils with a number of specific fatty acid compositions, there is interest in producing modifications of sunflower oil composition at the level of fatty acids and tocopherols in order to provide the food and some other industries (biodiesel production) with oils for special purposes.

The standard sunflower oil is predominantly composed of linoleic acid (C-18:2) and oleic acid (C-18:1), which make up about $90 \%$ of its total higher fatty acid content. Palmitic (C-16:0) and stearic (C-18:0) acids account for another 8-10\% of this content, while the remainder is comprised of trace amounts of several other higher fatty acids (Friedt et al., 1994).

Using induced mutations, seed treatments with gamma or X-rays and certain doses of mutagenic chemicals such as DMS, EMS and others, desirable mutations have been obtained that alter the fatty acid composition of sunflower oil (Friedt et al., 1994).

The first significant change to sunflower oil was made by Soldatov (1976), who treated seeds of the variety VNIIMK 8931 with a dimethyl-sulfate solution to obtain an induced mutation for a high oleic acid content. Using this material, he developed the first high-oleic sunflower variety, called Pervenets. All sunflower breeders wordlwide have used Pervenets as a source of genes for developing high-oleic sunflower hybrids

It is known that sunflower oil predominantly contains alpha tocopherol. Demurin (1993) discovered spontaneous mutations with different tocopherol forms and levels. First, he found a recessive gene $\left(t p h_{1}\right)$ in the line LG-15 that leads to the expression of $50 \%$ alpha and $50 \%$ beta tocopherol. The second mutation was the recessive $t p h_{2}$ gene, found in the line LG-17, which resulted in the expression of $5 \%$ alpha and $95 \%$ beta tocopherol. The third was the presence of the $t p h_{1} t p h_{2}$ in the line LG-24, leading to the manifestation of $8 \%$ alpha, $84 \%$ gamma and $8 \%$ delta tocopherol.

In genotypes containing both the $\mathrm{Ol}$ genes for a high oleic acid content and the $t p h_{1}, t p h_{2}$ and $t p h_{1} t p h_{2}$ ones for different tocopherol levels, a certain synergy occurs that results in a dramatic (20-fold) increase in oil oxidative stability compared with standard sunflower oil. (Karlović et al., 1997; Škorić et al., 2006).

Use of the genes for a high oleic acid content and the recessive tph genes for different tocopherol levels makes it possible to develop new sunflower hybrids with altered oil quality that will provide new products for the food industry and various non-food uses (biodiesel, cosmetic products, etc.) (Škorić et al., 2006). 
The incorporation of the genes for oil quality into highly productive lines and hybrids using molecular markers will enable sunflower breeders to increase the competitiveness of the sunflower relative to other field crops.

\section{CONCLUSIONS}

- Significant results have been achieved in the genetic study of the manifestation of heterosis and the mode of inheritance of agronomically important traits in the $\mathrm{F}_{1}$ and $\mathrm{F}_{2}$ generations in sunflower;

- Direct and indirect components of seed yield and oil yield per unit area have been particularly well studied;

- The general (GCA) and specific (SCA) combining abilities of a large number of inbreds have been studied and elite lines have been selected and used for the development of productive hybrids;

- Practices and methods for increasing the genetic variability of the cultivated sunflower have been established as a prerequisite for developing highlyproductive hybrids (seed yields of over $4 \mathrm{t} / \mathrm{ha}$ ) with resistance or tolerance to biotic and abiotic stresses;

- Genes for resistance or tolerance to a number of pathogens have been discovered in the wild species of the genus Helianthus;

- The wild sunflower species have been used to increase the genetic variability of the cultivated sunflower for tolerance of soil and atmospheric droughts;

- Using induced mutations, the fatty acid composition of sunflower oil has been altered. Of particular value is the transfer of $\mathrm{Ol}$ genes for a high oleic acid content and recessive tph genes for altered tocopherol levels (alpha, beta, gamma, delta), which has enabled the development of hybrids with different oil quality.

\section{REFERENCES}

Bajaj, R.K., Aujla, K.K., Chalal, G.S., 1997. Combining ability studies in sunflower (Helianthus annuus L.). Crop Improvement 24(1): 50-54.

Bedov, S., 1985. A study of combining ability for oil and protein contents in seed of different sunflower inbreds. Proc. $11^{\text {th }}$ Inter. Sunflower Conference. March 10-13, Mar del Plata, Argentina. pp. 675-682.

Borojević, S., 1981. Principles and methods of plant breeding (in Serbian). Novi Sad, pp.1-382.

Cecconi, F., Geetani, M., Srebernich, R., Luciani, N., 2000. Diallel analysis in sunflower (Helianthus annuus L.) genetic and phenotypic correlations for some agronomical and physiological characters. Proc. $15^{\text {th }}$ Inter. Sunflower Conference. June 12-15, Toulouse, France. 2: E1-E6.

Ćupina, T., Sakač, Z., 1989. Fiziološki aspekti formiranja prinosa suncokreta. Poljoprivredni fakultet. Institut za ratarstvo i povrtarstvo, Novi Sad. pp. 1-224.

Demurin, Y.N., 1993. Genetic variability of tocopherol composition in sunflower seeds. Helia 16(18): 59-62.

Djakov, A.B., 1981. Physiological basic of sunflower variety and ideotypes for limiting conditions. In: Proc. Eucarpia Sunflower Breeding. Prague, Czechoslovakia. pp.157-167. 
Dušanić, N., 1998. Uticaj gustine useva na dinamiku rastenja i prinos hibrida suncokreta, kao i neke mikro klimatske činioce. Ph.D. thesis. Faculty of Agriculture. University of Novi Sad.

El-Hity, M.A., 1992. Genetical analysis some agronomic characters in sunflower (Helianthus annuus L.). Proc. $13^{\text {th }}$ Inter. Sunflower Conference. September 7-11, Pisa, Italy. 2: 1118 1128.

Fick, G.N., 1975. Heritability of oil content in sunflower (Helianthus annuus L.). Crop. Sci. 15: 77-78.

Friedt, W., Ganssmann, N., Korell, M., 1994. Improvement of sunflower oil quality. Proc. EUCARPIA-Symposium of Oil and Protein Crops. Albena, Bulgaria. pp.1-29.

Gangappa, E., Channakrishnaiah, K.M., Harimi, M.S., Rames, S., 1997. Studies on combining ability in sunflower (Helianthus annuus L.). Helia 20(27): 73-84.

Goksoy, A.T., Turkec, A., Turan, Z.M., 2000. Heterosis and combining ability in sunflower (Helianthus annuus L.). Indian J. Agric. Sci. 70(8): 525-529.

Gundaev, A. I., 1966. The manifestation of heterotic effect in sunflower and obtaining of hybrid seeds on basis of male sterility. In: "Geterozis v rastenievodstve" Leningrad (in Russian). pp. 358-367.

Hladni, N., Škorić, D., Kraljević-Balalić, M., 2005. Heterosis for seed yield and components in sunflower. Genetica, 37(3): 253-260.

Joksimović, J., 1992. Evaluation of combining abilities in some inbred sunflower lines. Ph.D. thesis. Faculty of Agriculture, University of Novi Sad. pp. 1-157.

Joksimović, J., Marinković, R., Mihaljčević, M., 1994. Kombinacione sposobnosti za komponente prinosa $\mathrm{F}_{1}$ hibrida suncokreta (Helianthus annuus L.). Zbornik apstr. sa I Kongresa genetičara Srbije.Vrnjačka Banja. pp. 132-133.

Kovaček, A., Škaloud, V., 1990. Results of inheritance evaluation of agronomically important traits in sunflower. Helia 13: 41-46.

Kovaček, A., Škaloud, V., 1972. Combining ability and prediction of heterosis in sunflower (Helianthus annuus L.) Sci. Agric. Bohemoslovaca. 20(4): 263-273.

Kumar, A.A., Ganesh, M., Janila, P., 1998. Combining ability analysis for yield and yield contributing characters in sunflower (Helianthus annuus L.). Ann. Agric. Res., 19: 437440 .

Lande, S.S., Weginwar, D.G., Patel, M.C., Limbore, A.R., 1997. Gene action, combining ability in relation to heterosis in sunflower (Helianthus annuus L.) through line $\times$ tester analysis. J. Soils and Crops. 7(2): 205-207.

Leclercq, P., 1969. Une sterilite male cytoplasmique chez le tournesol. Ann Amelior. Plantes. 19(2): 99-106.

Lu, Y.H. Gagne, G., Grezes-Besset, B., Blanchard, P., 1999. Integration of a molecular linkage group containing the broomrape resistance gene Or5 into an RFLP map in sunflower. Genome 42: 453-456.

Marinković, R., 1984. Nacin nasledjivanja prinosa semena i nekih komponenti prinosa u ukrštanjima raznih inbred linija suncokreta. Ph.D. thesis. Faculty of Agriculture, University of Novi Sad.

Marinković, R., 1987. Analiza komponenti prinosa semena suncokreta (Helianthus annuus L.) s koeficijentom putanje I. Apstr. III Kongres geneticara Jugoslavije. Ljubljana. pp. 95.

Merrien, A., 1992. Some aspects of sunflower crop physiology. Proc. $13^{\text {th }}$ Inter. Sunflower Conference. September 7-11, Pisa, Italy. 2: 481-499.

Mihaljčević, M., 1989. Fenotipska stabilnost inbred linije i hibrida suncokreta tolerantnih prema Sclerotium bataticola Tanb. Ph.D. thesis. Faculty of Agriculture, University of Novi Sad.

Monti, L.M., 1986. Breeding plants for drought resistance: The problems and its relevance. Agriculture. Drought resistance in plants. Physiological and genetic aspects. October 1923, Amalfi. pp. 1 .

Ottaviano, E., 1986. Conclusive Remark's. Agriculture. Drought resistance in plants. Physiological and genetic aspects. October 19-23, Amalfi. pp.377.

Pacureanu-Joita, M., Vranceanu, A.V., Soare, G., Marinescu, A., Sandu, I., 1998. The evaluation of the parasite-host interaction in the system Heliantus annuus L. Orobanche cumana Wallr. in Romania. Proc. $2^{\text {nd }}$ Balkan Symposium on Field Crops. June 16-20. Novi Sad. pp. 153-157. 
Panchabhaye. P.M., Weginwar, D.G., Golhar, S.R., Pande, M.K., 1998. Detection of epistasis by using simlified triple test cross analysis in sunflower (Helianthus annuus L.). Ann. Plant Physiol. 12(2): 156-158.

Perez-Vich, B., Akhtouch, B., Velasco, L., Fernandez-Martinez, J.M., Knapp, S.J., Leon, A.J., Berry, S.T., 2004. Mapping QTL-s controlling sunflower resistance to broomrape (Orobanche cumana Wallr.). Proc. $16^{\text {th }}$ Inter. Sunflower Conference. August 29-September 2, Fargo, North Dakota, USA. 2: 651-657.

Petakov, D., 1992. Application of Griffing's methods in determination of combining ability of sunflower self-pollinated lines. Proc. $13^{\text {th }}$ Inter. Sunflower Conference. September 7-11, Pisa, Italy. 2: 1205-1210.

Пцачек, Е.М., Стебут, А.К., 1915. Подсолнечник. Труди Обласној опитној станции. Саратов.

Пцачек, Е.M., 1927. Узкородственое резмножение Inbreeding в применении к селекции подсолнечника. Журн. „Опитнаја агрономија југовостока.” T IV, вип. 1.

Пцачек, Е.М., 1930. Формообразователние процесси у подсолнечника под влијанием гибридизации и инцухта. "Труди Всес. Совешчанија по генетике, селекции и племенному живиноводству.” T IV.

Пмачек, Е.М., 1936. Семекција перекрестноопилјајушчихсја рестениј на основе инцухта: "Соц. Реконструкција сељскога хозјајства." No. 12.

Popov, A., Lazarov, M., Spirova, M., Stoyanova, Y., 1965. On the problems in obtaining hybrid seeds in sunflowers (in Bulgarian). Izdatelstvo na Bugarskata Akademia na Naukite. Sofia.

Putt, E.D., 1966. Heterosis, combining ability and predicted synthetics from a diallel cross in sunflower (Helianthus annuus L.). Can. J. Plant Sci., 46: 59-67.

Rao, N.M., Singh, B., 1977. Inheritance of some quanititative characters in sunflower (Helianthus annuus L.). Pakistan J. Agr. Res. 2: 144-146.

Rather, A.G., Sandha, G.S., Bajaj, R.K., Narinder, K., 1998. Genetic analysis for oil yield and its components in sunflower. (Helianthus annuus L.). Crop Improvement. 25. 2: 226228.

Sassikumar, D., Gopalan, A., Thirumugan, T., 1999. Combainig ability analysis in sunflower (Helianthus annuus L.). Trop. Agric. Res. 11: 134-142.

Schuster, W., 1964. Inzucht und Heterosis bei der Sonnenblume. Habilitationschrift. Wilchem Schmit Verlag. Giessen. pp. 1-135.

Seiler, G.J., 1983. Evaluation of wild sunflower species for potentional drought tolerance. Proc. Sunflower Research Workshop. National Sunfl. Assoc. Bismarck, ND. USA. p.13.

Seiler, G.J., 1986. Evaluation of responses of interspecific and cultivated sunflower hybrids to water stress. Proc. Sunflower Research Workshop. National Sunfl. Assoc. Bismarck, ND. USA. pp. 9-10.

Sharma, J.R., 1994. Principles and Practice of Plant Breeding: 1-599. Tata McGraw-Hill Publishing Company Limited, New Delhi.

Sheriff, N.M., Appandurai, R., 1985. Genetic variability in some quantitative traits of sunflower. Madras Agric. J., 72(9): 539-540.

Shrinivasa, K., 1981. Inheritance of fertility restoration and oil content in sunflower (Helianthus annuus L.). Thesis abstr. India. 8(1): 70-71.

Shudhaker, D., Seetharam, A., Sindai, S., 1984. Analysis of combining ability in sunflower. Oilseeds J. 1: 157-166.

Sindagi, S.S., Kulkarni, R.S., Seetharam, A., 1979. Line $\times$ tester analysis of the combining ability in sunflowers. (Helianthus annuus L.). The Sunflower Newsletter, 2.2: 11-12.

Singh, S.B., Labana, K.S., Virk, D.S., 1989. Detection of epistatic, additive and dominant variation in sunflower. Indian J. Genet. Plant Breed. 47(3): 243-247.

Škorić, D., 1974. Correlation among the most important characters of sunflower in $F_{1}$ generation. Proc. $6^{\text {th }}$ Inter. Sunflower Conference, July 22-24, Bucharest, Romania. pp. 283-289.

Škorić, D., 1975. The ability of use of heterosis in sunflower on the basis of male sterility (in Serbian). Ph.D. thesis. Novi Sad

Škorić, D., 1976. Harakter nasledovanija soder_anija masla v semenah pervoga pokolenija i komponenti geneticeskoj izmenjcivosti podsolnecnika. Proc. $7^{\text {th }}$ Inter. Sunflower Conference, Krasnodor, SSSR. pp. 191-195.

Škorić, D., 1980. Desired model of hybrid and the newly developed NS-hybrids. Helia 3: 19-24. 
Škorić, D., Vrebalov, T., Ćupina, T., Turkulov, J., Marinković, R., Maširević, S., Atlagić,J., Tadić, L., Sekulić, R., Stanojević,D., Kovačević, M., Jancić.V., Sakač, Z., 1989. Sunflower (in Serbian). Nolit, Beograd, Jugoslavia. pp. 1-635.

Škorić, D., 1992. Achievements and future directions of sunflower breeding. Field Crops Research 30(3-4): 231-371.

Škorić, D., Jocić, S., Molnar, I., 2000. General (GCA) and specific (SCA) combining abilities in sunflower. Proc. $15^{\text {th }}$ Inter. Sunflower Conference. June 12-15, Toulouse, France. 2: E23E30.

Škorić, D., Marinković, R., Jocić, S., Jovanović, D., Hladni, N., 2002. Dostignuca i dalji pravci u i oplemenjivanju suncokreta i izbor hibrida za setvu u 2002. godini (in Serbian). Periodical of Institute of Field and Vegetable Crops Novi Sad. 36: 147-160.

Škorić, D., Jocić, S., Jovanović, D., Hladni, N., Marinković, R., Atlagić, J., Panković, D., Vasić, D., Miladinović, F., Gvozdenović, S., Terzić, S., Sakač, Z., 2006. Achievements of sunflower breeding ( In Serbian). Periodical of Institute of Field and Vegetable Crops Novi Sad. 42: 131-173.

Soldatov, K.J., 1976. Chemical mutagenesis for sunflower breeding. Proc. $7^{\text {th }}$ Inter. Sunflower Conference. Krasnodar, SSSR. pp. 352-357.

Sukno, S., Melero-Vera, J.M., Fernandez-Martinez, J.M., 1999. Inheritance of resistance to Orobanche cumana Wallr. in six sunflower lines. Crop. Sci. 39: 674-678.

Tang, S., Yu, J.K., Slabaugh, M.B., Shintani, D.K., Knap, S.J., 2002. Simple sequence repeat map of the sunflower genome.. Theor. Appl. Genetic 105: 1124-1136.

Tang, S., Heesacker, A., Kishore, V.K., Fernandez, A., Sayed, E.S., Cole, G., Knapp, S.J., Leon, A.J., Velasko, L., Fernandez-Martinez, J.M., Berry, S.T., 2004. Quantitative trait loci for broomrape (Orobanche cumana Wallr.) resistance in sunflower. Theor. Appl. Genetic. 109: 92-102.

Tyagi, A.P., 1988. Combining ability analysis for yield components and maturity traits in sunflower (Helianthus annuus L.). Proc. $12^{\text {th }}$ Inter. Sunflower Conference. July 25-29, Novi Sad, Yugoslavia. 2: 489-493.

Vranceanu, A.V., Tudor, V.A., Stoenescu, F.M., Parvu, N., 1980. Virulence groups of Orobanche cumana Wallr., Differentional hasts and resistance sources and genes in sunflower. Proc. $9^{\text {th }}$ Inter. Sunflower Conference. Torremolinos. Spain. pp. 74-83.

Yagodkin, I.G., 1937. Применение методи инцухта и диалмелних скрешчеваний в културе подсолнечника. „Семекция и семеноводство.” No.1.

\title{
ANÁlisis DEL POTENCIAL HETERÓTICO PARA LAS CARACTERÍSTICAS AGRONÓMICAS DE GIRASOL (Helianthus annuus L.) IMPORTANTES
}

\author{
RESUMEN
}

Las investigaciones de consanguinidad (endocria) y de heterosis en girasol, se están realizando desde hace más de 80 añs. La aplicación práctica del fenómeno de heterosis en esta especie, empezó tras el descubrimiento de la fuente de esterilidad masculina citoplasmática oportuna, en el año 1969 y el descubrimiento del gen de restauración de fertilidad.

Muchos autores registraron una significante presentación de heterosis para el rendimiento de la semilla y componentes del rendimiento. También fue investigado detalladamente el modo de heredar las características agronómicas importantes en las generaciones $\mathrm{F}_{1} \mathrm{y} \mathrm{F}_{2}$. Se han establecido correlaciones positivas entre las líneas parentales y el híbrido $\mathrm{F}_{1}$. OKS y PKS para el rendimiento y las componentes de rendimiento, resultan bien estudiados. Se ofrecieron las soluciones de cómo incrementar el índice de cosecha y la capacidad del aceptador del asimilado tanto como la contribución de los parámetros fisiológicos individuales en el proceso de incremento del rendimiento.

Para incrementar el efecto de heterosis para el rendimiento de semilla y las componentes de rendimiento directas e indirectas, es preciso incrementar 
la variabilidad genética del material de preselección, incrementar la eficacia de la fase de consanguinidad y promover y acelerar el proceso de valoración de OKS y PKS utilizando los marcadores moleculares y otros métodos biotecnológicos.

El contenido de aceite en la semilla debe ser aumentado por encima de $55 \%$ utilizando el método de selección recurrente. Una atención especial de los programas de selección debe prestarse en creación de los híbridos alto oleicos (>95\%) con alto potencial genético para el rendimiento de aceite, resistencia a las enfermedades dominantes y amplia adaptabilidad, que se utilicen con fines industriales (producción de biodiesel o hidrógeno). Para prolongar la estabilidad del aceite de girasol, es preciso introducir beta, gama y delta tocoferoles en vez de alfa tocoferol, tanto como los genes $\mathrm{Ol}$. La variabilidad génica existente del girasol cultivado, posibilita la creación de los híbridos con el potencial genético para el rendimiento de semilla por encima de 6 t/ha y con el contenido de aceite por encima de $55 \%$. Pero, los rendimientos de girasol en la producción comercial más a menudo oscilan entre 1,5 y 3,0 t/ha. Existen muchos factores limitadores que impiden la realización de altos potenciales genéticos de este cultivo. Su solución posibilitará que el rendimiento de girasol se estabilice en el nivel de 4 t/ha o más.

Las enfermedades representan el principal factor limitador que influye en la producción de girasol en todas las partes del mundo en los cuales se produce girasol. La creación de una germoplasma exótica, a través de continuación de la utilización de las especies silvestres de girasol, la hibridación de las especies lejanas y la transformación genética, debe ser utilizada para la creación de un gen de resistencia hacia todos los patógenos dominantes y el jopo del girasol.

Los métodos de selección eficaces deben ser utilizados con el fin de aumentar la tolerancia del girasol hacia la sequía aérea y del terreno de salinidad del terreno, y de lograr una más amplia resistencia hacia herbicidas.

\title{
ANALYSE DU POTENTIEL DE VIGUEUR HYBRIDE POUR DES CARACTÉRISTIQUES AGRONOMIQUES IMPORTANTES DU TOURNESOL (Helianthus annuus L.)
}

\author{
RÉSUMÉ
}

L'étude de l'autogamie et de l'hétérosis du tournesol se fait depuis plus de 80 ans. L'application pratique du phénomène d'hétérosis dans cette espèce a commencé après la découverte d'une source de stérilité cytoplasmique mâle favorable en 1960 et de celle de gènes de restauration.

De nombreux auteurs ont rendu compte d'une manifestation importante d'hétérosis pour le rendement en graines aussi bien que pour les composantes du rendement. De plus, le mode d'hérédité d'importantes caractéristiques agronomiques dans les générations $\mathrm{F}_{1}$ et $\mathrm{F}_{2}$ a été examiné en détail. Des corrélations positives importantes ont été établies entre les lignées parentales dans les hybrides $F_{1}$. Les effets de AGC et de ASC pour le rendement et les composantes de rendement ont été étudiés à fond. Des solutions sur la manière d'augmenter l'index de moisson et de capacité sink ainsi que les contributions des paramètres physiologiques individuels dans le procédé d'augmentation du rendement ont été suggérées.

Pour augmenter les effets d'hétérosis sur le rendement en graines et en huile et les composantes directes et indirectes du rendement, il faut augmenter 
la variabilité génétique du matériel de présélection, augmenter l'efficacité des phases d'autogamie et développer et accélérer le procédé d'évaluation de AGC et de ASC en utilisant les marqueurs moléculaires et les autres méthodes de la biotechnologie.

Il faut augmenter le contenu d'huile dans la graine à plus de $55 \%$ en utilisant la méthode de sélection récurrente. Dans les programmes de sélection, il faut accorder une attention particulière au développement d'hybrides à haute teneur oléique ( $>95 \%)$, à grand potentiel génétique pour le rendement d'huile, à résistance aux maladies dominantes et à grande adaptabilité à l'environnement qui pourraient être utilisés dans des buts industriels (production de biodiesel ou d'hydrogène). Pour prolonger la stabilité de l'huile de tournesol, il faut incorporer des tocophérols bêta, gamma et delta plutôt que des tocophrols alpha, parallèlement aux gènes $\mathrm{Ol}$. La variabilité génétique actuelle du tournesol de culture permet la création d'hybrides à potentiel génétique pour un rendement de graines de plus de 6 t/ha et avec contenu d'huile de plus de $55 \%$. Cependant, les rendements du tournesol dans la production commerciale varient le plus souvent entre 1,5 et 3,0 t/ha. Il existe de nombreux facteurs limitatifs qui empêchent la réalisation des grands potentiels génétiques de cette culture. Leur élimination permettra au rendement du tournesol de se stabiliser à un niveau de $4 \mathrm{t} / \mathrm{ha}$ ou plus.

Les maladies sont le facteur limitatif principal de la production du tournesol dans toutes les régions du monde où on le cultive. La création de plasmas germinatifs exotiques par l'utilisation additionnelle d'espèces de tournesol sauvage, l'hybridation d'espèces éloignées et la transformation génétique doivent être utilisées dans la création de gènes résistants à tous les pathogènes dominants et à l'orobanche.

Il faut utiliser des méthodes de sélection efficaces pour augmenter la tolérance à la sécheresse de l'air et du sol et à la salinité et pour obtenir une plus grande résistance aux herbicides. 
